\title{
Introducing Geotourism Attractions in Toroud Village, Semnan Province, IRAN
}

\author{
Aref Shirazi \\ Amirkabir University of Technology \\ Tehran, Iran
}

\author{
Adel Shirazy \\ Shahrood University of Technology \\ Semnan, Iran
}

\begin{abstract}
Today, the role of tourism industry is more and more developed in any country and all countries try to have the maximum use of this industry, , as one of the important indicators of development, and the place of each country is identified in the optimal use of this important issue. In the meantime, despite the fact that Iran has received significant potential, Iran has not been able to use it as it needs to be. This matter is not focused solely on places and recreation centers, ancient and cultural, because we also have other wellknown potentials in other natural arenas, which so far have received less attention in this regard. An important feature of ecotourism is one of these. But the tourism industry has stepped up in the last decade and has entered a much more serious and recent area of utilization and exploitation of the capabilities of geo-tourism. Along with the main pillar of the industry, the idea of creating geoparks by the UNESCO Organization is to protect and identify the 4 billion years old Earth heritage. Meanwhile, Iran, with a significant and very important history of geology, which has long been of interest to all foreign and domestic researchers and researchers, has a great potential and potential for creating geoparks. One of these areas is the Toroud village and its surroundings in the southern part of Shahroud city, Semnan province of Iran. In this article, in addition to introducing this very important area from the perspective of the writer as the center of decorative and semi-precious stones in Central Iran, it has tried to attract the attention of all governmental and non-governmental officials along with other interested researchers.
\end{abstract}

Keywords: Tourism; Ecotourism; Geotourism; Geopark; Toroud; Semnan; Iran

\section{INTRODUCTION}

Geotourism consists of two parts: geo and tourism. The first part includes geological attractions, geomorphology and mining heritage [1]. The second part, as a multidisciplinary theme, includes all the infrastructure of the tourism industry, including interpretation, management, accommodation, tours, and unlike ecotourism, which places the attractions of nature in the center of attention, the industry is generally attracted by attractions Inanimate nature deals [2]. Geotourism audiences are not only geologists and geomorphologists, but also ordinary tourists and nature enthusiasts. During the activities of geotourism, tourists, while visiting the beautiful phenomena and special geology and geomorphology, familiar with the foundations of their emergence, find their essential significance [3]. In China, due to the existence of geosites and beautiful landscapes, local authorities have focused on geotourism as one of the tools for new economic growth [4]. By creating each Geo site, the Chinese have created many jobs each year, and have more than 1 million visitors annually from geotourism [5]. Scientific tourism is another branch of tourism that can be attributed to scientific activities. For example, in mining, mineral processing, in which complex industrial methods are used. Or geological, archaeological or even mineral exploration (sampling, geochemistry, implementation of the results of statistical studies in field operations) can be used as scientific tourism goals for students and those interested in this field [6-12] .

The Geo-Parks Information System of Iran was established in 2004 with the assistance of the Geological Survey of Iran, based on the UNESCO Geo-Parks Network's International Geoscience Network Model, by the Geosciences Database of Iran. A serious effort has also been made to study geo-tourism since 2005 for a part of the western part of Qeshm Island, and now besides Qeshm Island, the geopark project of Sabalan region in Ardebil province is also being studied and compiled [13]. So here we will mention the number of countries and the number of geoparks created by them supported by UNESCO.
China with 39 geoparks, and Germany with 5 geoparks, Spain 13 geoparks and Italy 10 geoparks [14]. Many geological structures can be identified by satellite imagery and remote sensing studies $[15,16]$.

\section{GEOGRAPHIC LOCATION AND GEOLOGY OF THE STUDY REGION}

The Toroud village is located in the southern part of the Shahroud city, on the edge of the desert. The village is located in Semnan Province, Shahroud, in the central part of the Toroud rural district in terms of political-administrative divisions [17]. The geographical location of the village is located at $35^{\circ} 25^{\prime} 38^{\prime \prime} \mathrm{N}$ and $55^{\circ} 00^{\prime} 55^{\prime \prime} \mathrm{E}$. Due to the geographical location of the village from the north to the Dolab rangeland, south to the Kavir desert, to the Kal Shor River (first Turan Wildlife Park) and the West to the Baamo rangelands. Distance from village to Shahrood city is more than $120 \mathrm{~km}$ (Figure 1,2) [18]. Its population is about 4500 people, and its relatively large area $(20013 \mathrm{~km} 2)$ has a large population dispersion. More than half of its population has migrated to cities such as Shahrood. The jobs of people in this region are livestock farming, including camel and sheep, and also agriculture. The agricultural products of the barley, wheat, cotton, garlic, turnips and tree products of those dates are limited to figs and pomegranates.

The agricultural lands are drunk by aqueduct. In 1953, an earthquake with 6.9 richter magnitude completely destroyed the Toroud village, and the current Toroud was built adjacent to the ruined village with clay and mud and wood. According to the quotations of the distant past, this area was the passageway of caravans, and along the southern edge of the desert, such as Khour, Biabanak, Jandagh and northern areas such as Shahrood, Damghan and Beyyrjmand, it was important in terms of distribution of goods. The carpet weaving has begun in the region about 40 years ago with the Naine design, and is now also popular. The area is rich in geology and minerals, and there are copper, lead, bentonite, 
barite, manganese and some gemstones from the opal and agate family and gold minerals in it.

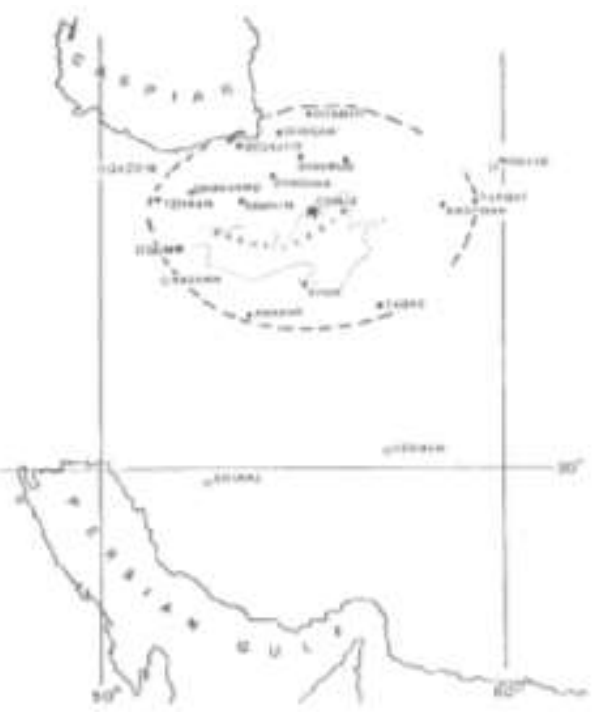

Fig1. Location Map of the Toroud village [18].

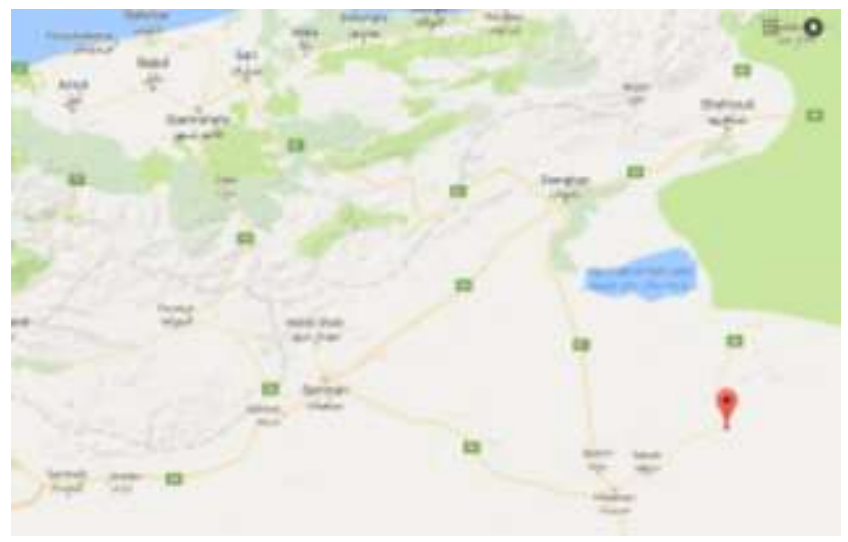

Fig 2. Torud location on the map

\section{CENTRAL IRANIAN BLOCK GEOLOGY}

In the constructional divisions of Iran, which was reported by Stocklin in 1968, Central Iran's unit includes all parts of the country that lies between the Alborz mountains in the north and the Esfandagh-Marivan in the south and the Loot block in the east as a triangle. According to this report, central Iran, like the adjacent regions in the first period, has a characteristic feature, but in the second and third period (the beginning of Alpine movements), it has been a very moving region for orthogonal movements. The intrusions and influences of the internal masses are witnessed, and eventually this zone is compressed in the last phase of the Alpine, in which folds, faults, and complex deformations have arisen. This area is introduced as a unit for geological characteristics. The whole central Iran zone is divided into four parts. The most important part that includes the plain of the desert and the study area is also the Neogene-Quaternary basin. Ofcourse, all the large inner basins of Central Plateau are formed in the late Miocene. The bottom of the basin in Quaternary and even now is gradually subsiding [19].

\section{GEOTOURISTIC \& TOURIST AREAS OF THE REGION}

Major sources of water, such as Haj Aligholi Salt Lake, is one of the largest salt marshin Iran. The lake is a triangular state with its head in the north and the lake's water catchment area is about $2500 \mathrm{Km}^{2}$. The water of this lake is very salty and is very beautiful at sunset from the Siahkooh peaks. Salt Lake is the basin of many of the central rivers in Iran, and there are many marshes around it, although there are no aquatic species in the lake, but in the winter, a significant number of aquatic migratory birds come to this lake and the surrounding rivers. Years ago, in the summer, a number of flamingos were seen in its southern regions. Other ponds, such as the Abgirmakoosh, the Beerezard, the Asbeqadir are mostly dried up and the flood gathering place.

\section{The rivers of the region include:}

- Bandalikhan river: This river is the most important river in the protected area of the desert. It is the source of this river from the mountain of Khersang, which creates the Jajrood River. The river crossed the protected areas of Varchin, Jajrud and Khojir National Park in Parchin, which enters the Varamin Plain, has several branches and is used for irrigation, and drains the Jajroud River and the Tehran sewage system in the plain of Varamin Received in Bandalah Khan entered the protected area.

- Gharechay river: From Rasund Mountains in southern Arak, after passing from Arak and Saveh, the river Qomrood river into Salt Lake. The upper branch of the river near the unprotected deserts of the winter habitat is the habitat of various aquatic migratory birds, especially the cave, the ducks and green ducks, and dry ducks such as crests and winds in all seasons and it is important.

Ainorashid, Abmahale, Shekarab, Nakhjir, Cheshmeh Shahi, siahkooh are the most famous springs of Kavir National Park, which are currently supplying water to Ghasre Baharam. Cheshmeshahi Spring is a passionate water that has been driven by the tube to Ghasrebahram for public use. Around the fountain, the straw and cam tree are abundantly seen. The other springs that feed the cattle include: Ainorashid, Hozaghamohammad, Abmahale, Boz, Sorkh, Peyghambar, Abgole, Ghajariye, Shekarab, Talhe, Malekabad, Zanboori, Ab-barik, Lakab, Mirabderaz. In addition to having desert plant communities, semi-desert and vegetation communities of saline soils in mountainous parts with steppe plant communities. Many of the sandy and sandy beaches are characteristic of the most desert areas. Desert National Park plants are drought-tolerant (Xerophyte) and passionate (halophyte) species, which have been exposed to water scarcity as a live indicator of adverse ecological conditions for a fraction of the year, and for survival and adaptation to shortages Water and salinity of the soil find a special building that indicates the dryness and biological constraints of these plants to deal with dehydration, high temperatures, small leaves leading to thorns that indicate the dryness and biological constraints of these plants to deal with dehydration The heat of the small leaves leads to thorns. 


\section{BEAUTIFUL NATURAL AREAS FOR} THE COMMON PEOPLE

In the Toroud village, considering the particular geological position, you can explore the beautiful developments of desert nature. One of these beautiful areas is deserts. (Figure $3,4)$

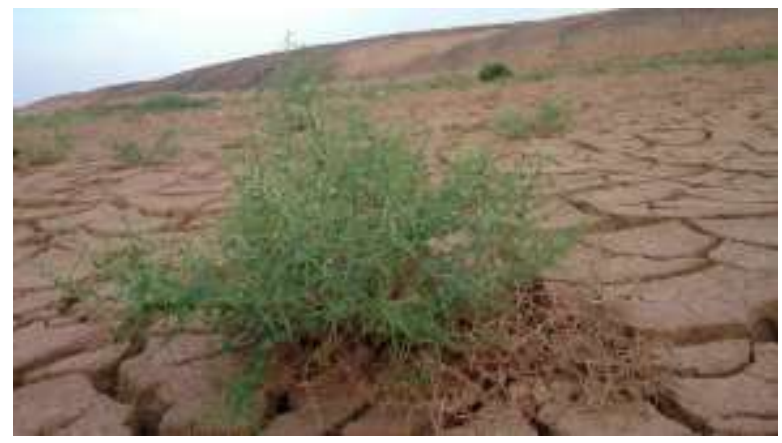

Fig 3. A view of Alhagi bush in torud village.

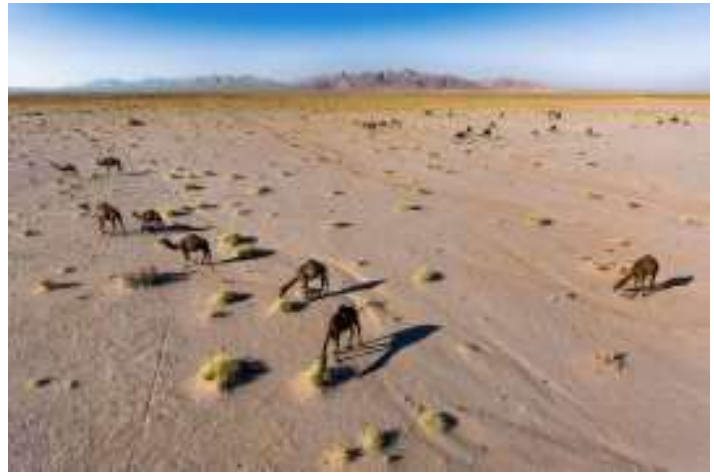

Fig 4. Kooh Pineh area $18 \mathrm{~km}$ north of Trod

\section{ATTRACTIONS IN THE REGION'S GEOLOGY}

\section{1- Gully erosion}

A gully is a landform created by running water, eroding sharply into soil. Gullies resemble large ditches or small valleys, but are meters to tens of meters in depth and width. When the gully formation is in process, the water flow rate can be substantial, causing a significant deep cutting action into soil [20]. According to the gully map (Figure 5), the surface of gully erosion in toroud basin is about 97.25 hectares [21].

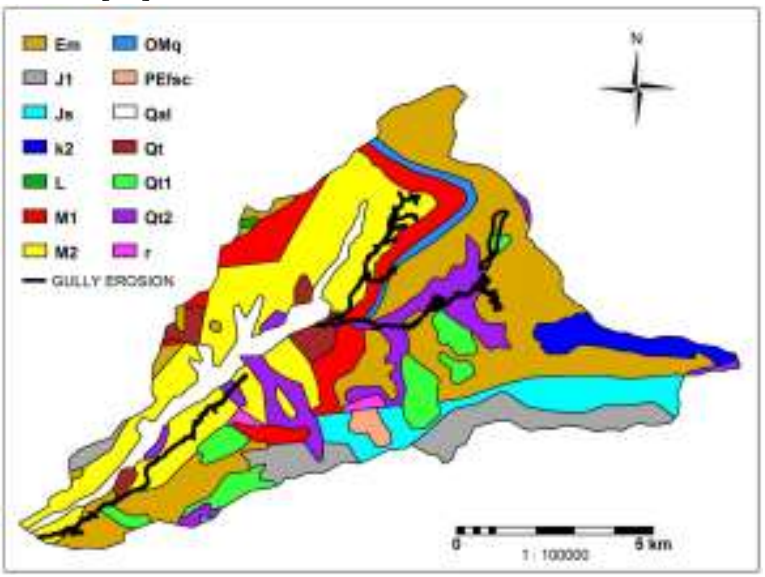

Fig 5. geology of toroud basin and gully erosion extension [21].
The research on the lithology and soil type in Toroud basin shows that most erodible sediments in this region are related to the age of Eocene and Miocene include Marl, Limestone, Shale, Sandstone, Conglomerate and etc. [21]. The high amount of gully surface is related to the Eocene period include, Marl, Marl stone, Limestone and tuff that is equal 41.65 percent of whole gully erosion in this region [21]. Pictures of gullies are shown in the figures 6 and 7.

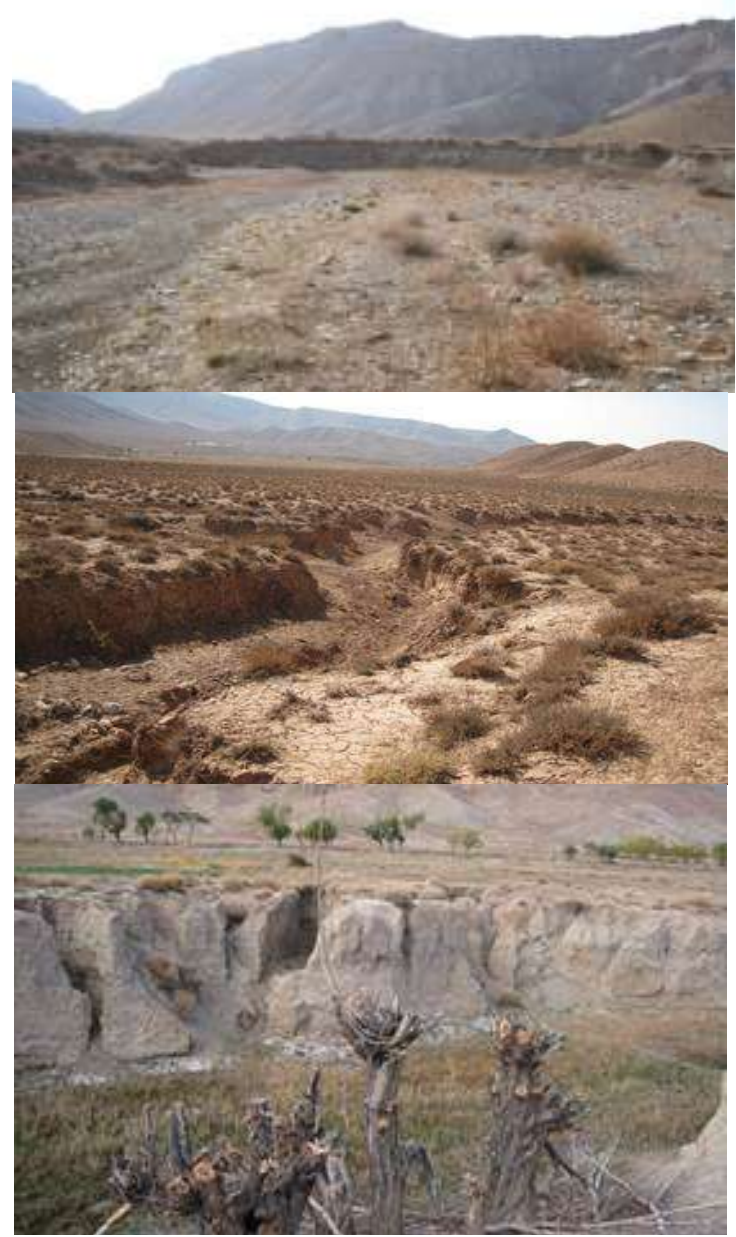

Fig 6.Piping in the gully

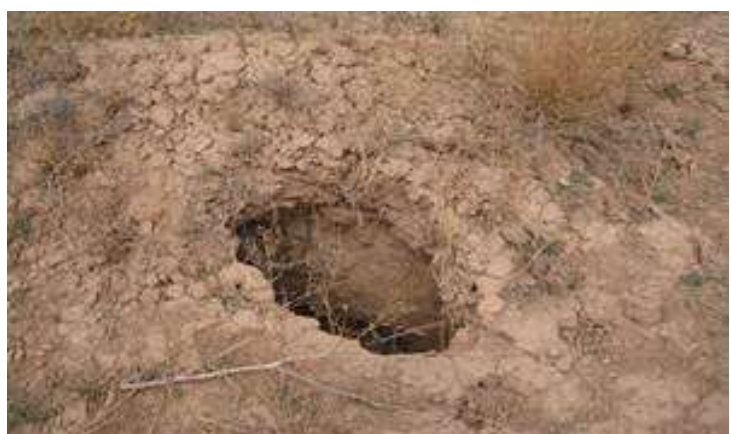

Fig 7.Hole in the gully

There are many researchers that are interested to study 


\section{2- ornamental and semi-precious stones}

Among the prominent features of this area are the existence of different mines that create the special ornamental and semiprecious stones. Some of the stones that have been harvested from this area and even sold by villagers:

Amethyst, turquoise, crystalline quartz (known as Dorrenajaf), Onyx (Soleymani agate), tree opal, varieties of agates (green and purple and red, etc.), moss agate and etc. (Figure 8).

- Analcime or analcite (from the Greek analkimos "weak") is a white, gray, or colorless tectosilicate mineral. Analcime consists of hydrated sodium aluminium silicate in cubic crystalline form. Its chemical formula is NaAlSi2O6.H2O. Minor amounts of potassium and calcium substitute for sodium. A silver-bearing synthetic variety also exists (Ag-analcite) [22].

- Amethyst is a violet variety of quartz. The name

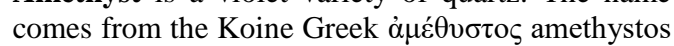
from $\dot{\alpha}-\mathrm{a}-$, "not" and $\mu \varepsilon \theta \dot{\sigma} \sigma \kappa \omega$ methysko / $\mu \varepsilon \theta \dot{v} \omega$ methyo, "intoxicate", a reference to the belief that the stone protected its owner from drunkenness[23]. The ancient Greeks wore amethyst and carved drinking vessels from it in the belief that it would prevent intoxication. Amethyst is a semiprecious stone often used in jewelry and is the traditional birthstone for February.

- Barite is a mineral consisting of barium sulfate (BaSO4). Barite is generally white or colorless, and is the main source of the element barium [24].

- Agate is a common rock formation, consisting of silica, chalcedony and quartz as its primary components. the formation consists of a wide variety of colors and grain size. Agates are primarily formed within volcanic rocks and metamorphic rocks. These stones have been seen to have dated back as far as Ancient Greece, however with their mediocre durability, their everyday uses are most commonly as decorations or jewelry [25]. Lace agate is a variety that exhibits a lace-like pattern with forms such as eyes, swirls, bands or zigzags [26].

- Cerussite (also known as lead carbonate or white lead ore) is a mineral consisting of lead carbonate ( $\mathrm{PbCO} 3)$, and an important ore of lead. The name is from the Latin cerussa, white lead [27].

- Calcite is a carbonate mineral and the most stable polymorph of calcium carbonate $(\mathrm{CaCO} 3)$. Calcite is derived from the German Calcit, a term coined in the 19th century from the Latin word for lime, calx (genitive calcis) with the suffix -ite used to name minerals. It is thus etymologically related to chalk [27]. This mineral is found in most of areas of iran [28]

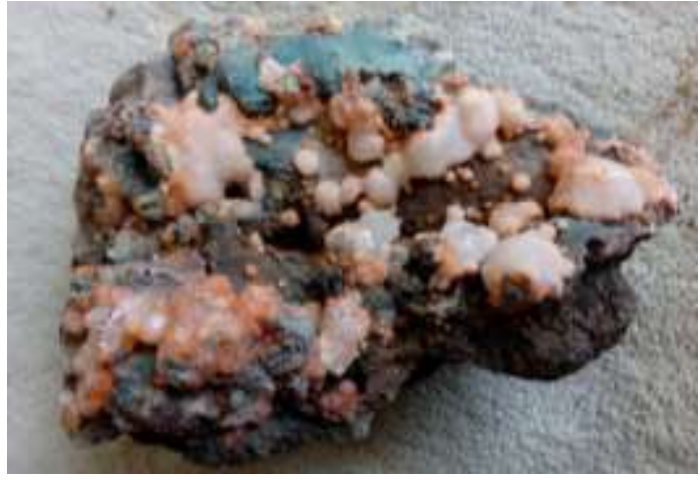

A

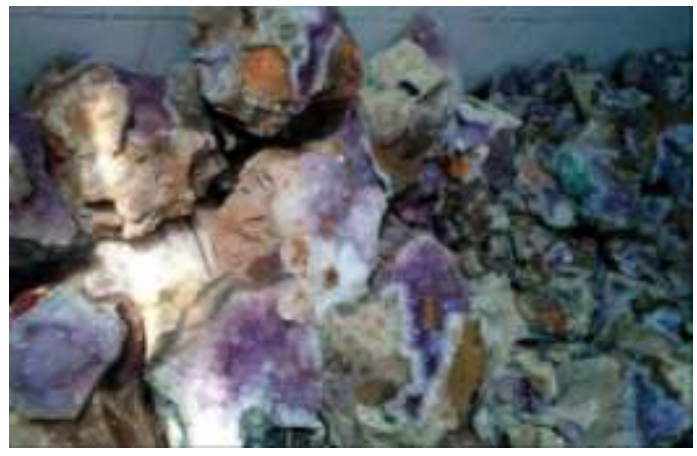

B

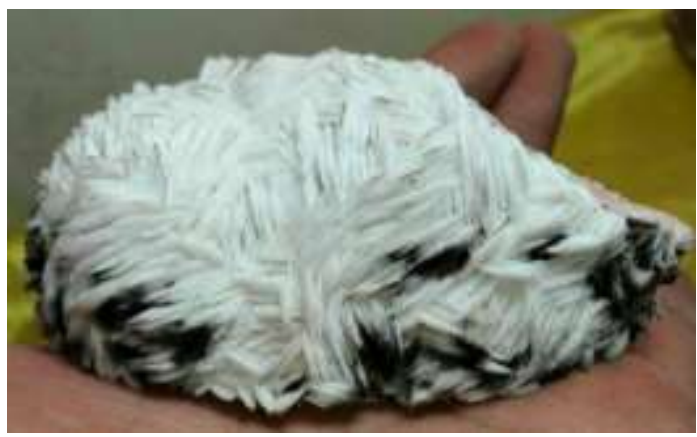

$\mathrm{C}$

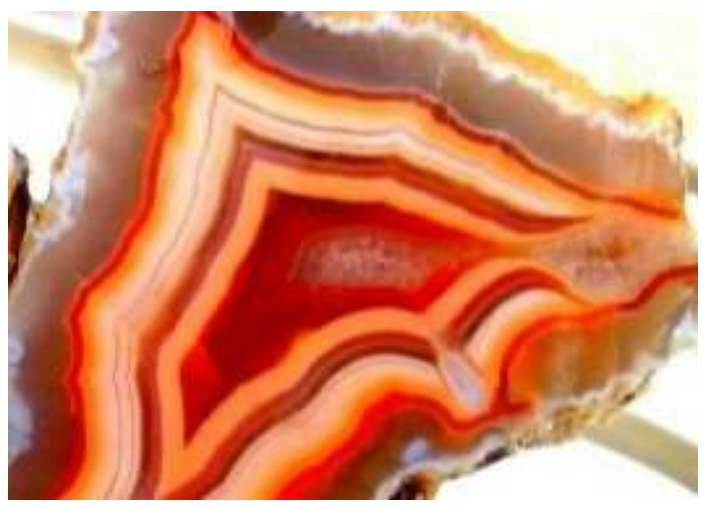

$\mathrm{D}$ 
International Journal of Science and Engineering Applications

Volume 9 - Issue 06, 79 - 86, 2020, ISSN:- 2319 - 7560

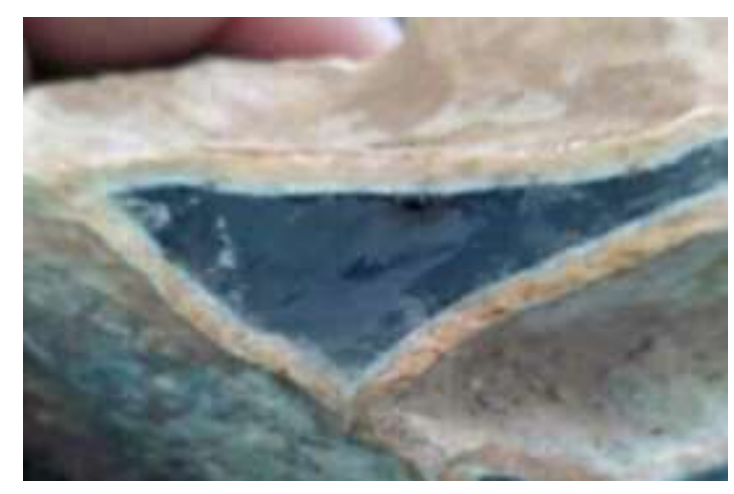

E

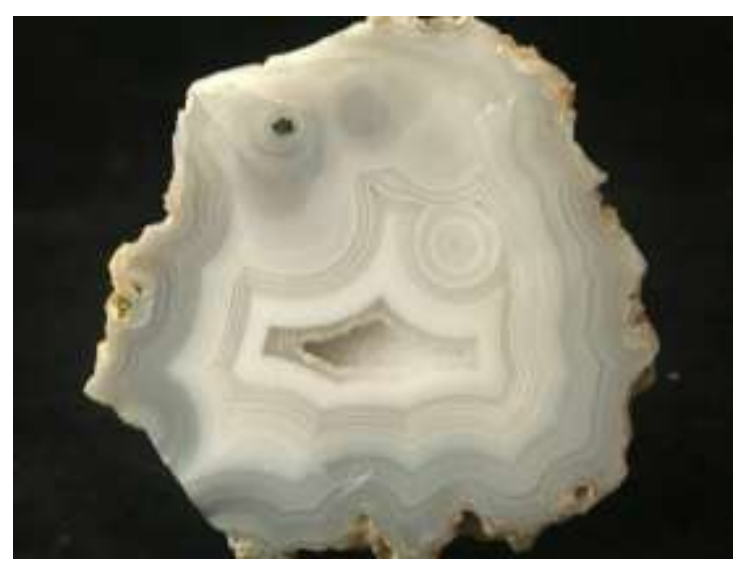

F

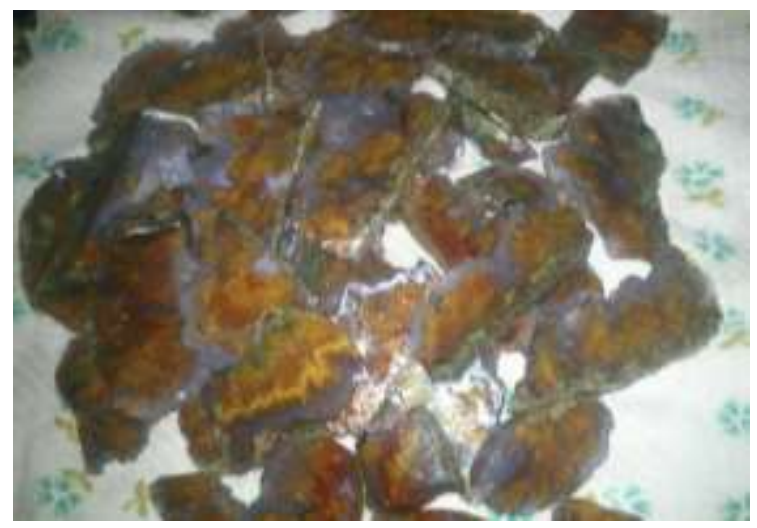

G

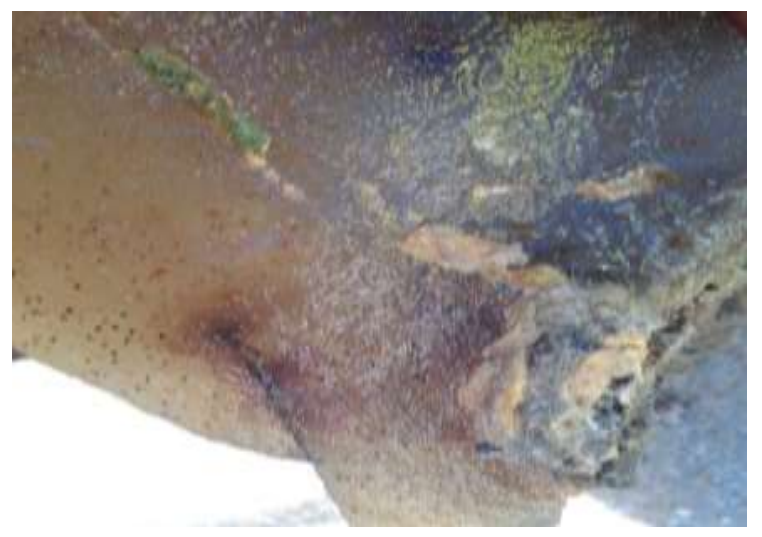

$\mathrm{H}$

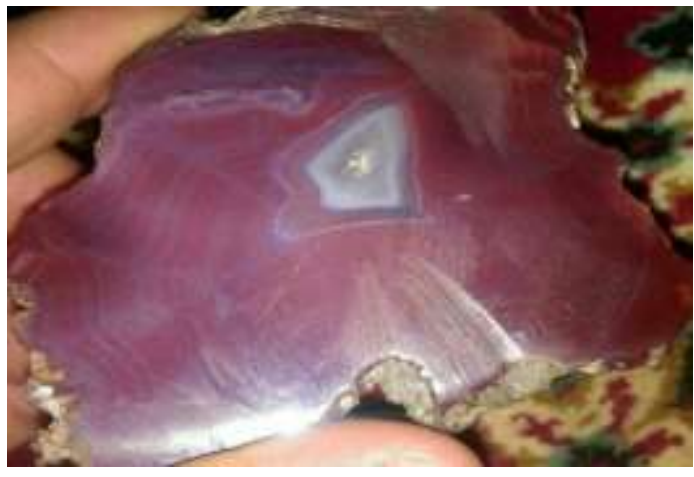

I

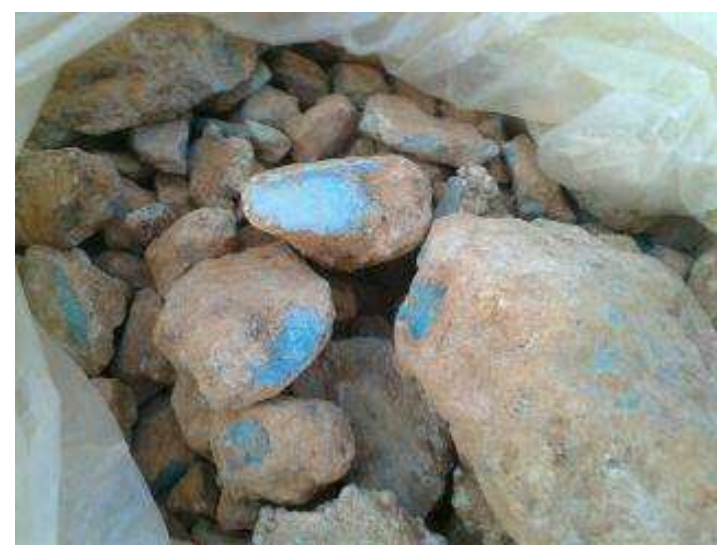

J

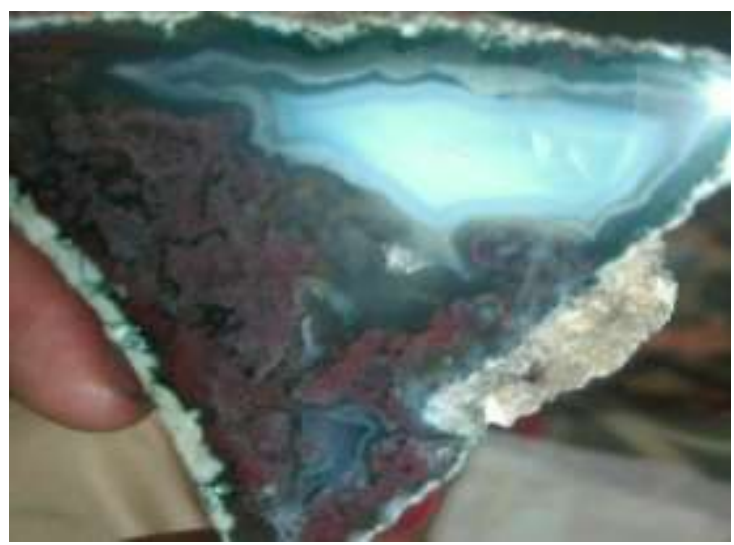

K

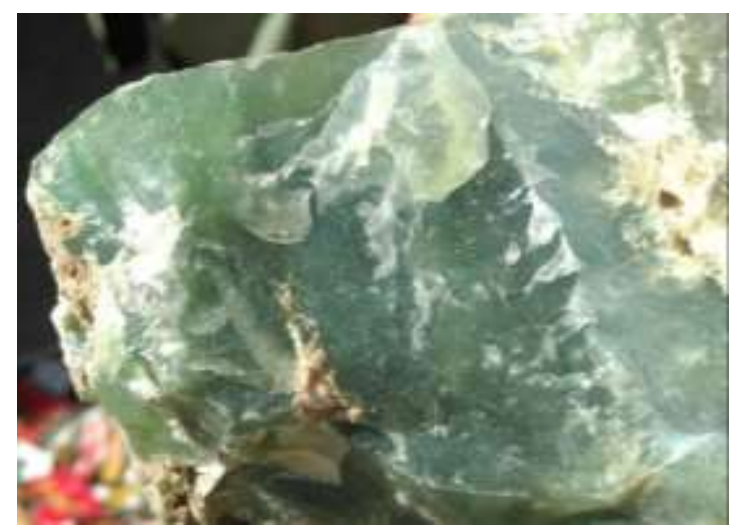

L 


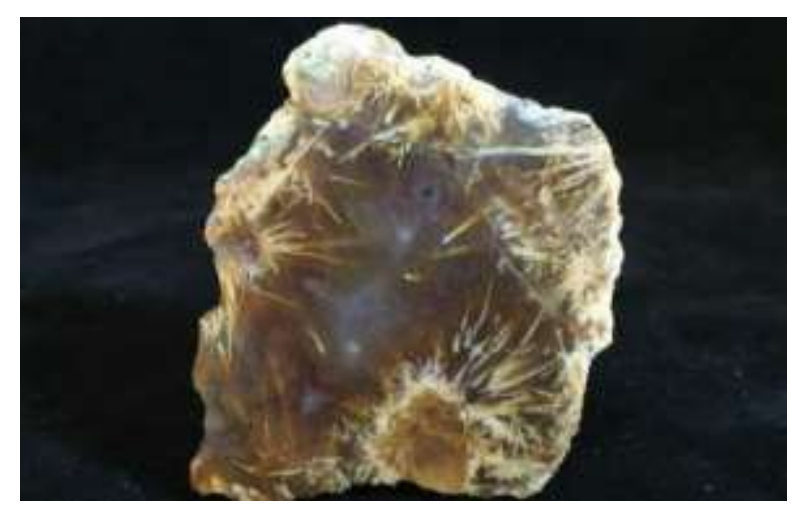

M

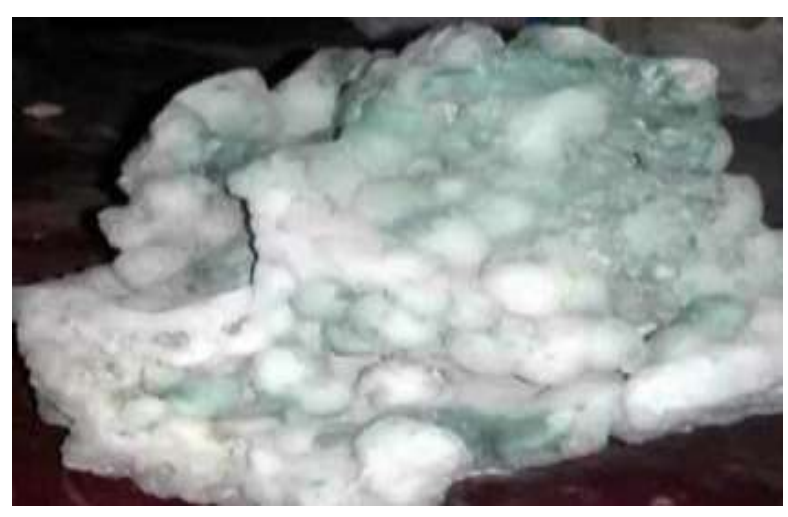

$\mathrm{N}$

Fig 8. Common rocks and minerals found in the torud

(A: Analsim , B: Amethyst, C: Barite, D: Agate, E: Dendritic Agate, F: geod agate, G: Moss Agate, H: Silica, I: Jasper, J: Turquoise, K: Onyx, L: Jade, M: Cerussite ,N: calcite )

\section{THE PUBLIC BEAUTIES OF THE AREA}

The Toroud village, due to its historic history, has historical attractions as well as natural attractions. Specific species of this region, such as the camel of the desert, the Asian zebrafish (Khar Turan) and the Cheetah, and etc. are among the other natural charisma of the plain of Kavir desert (Figures 9-11).
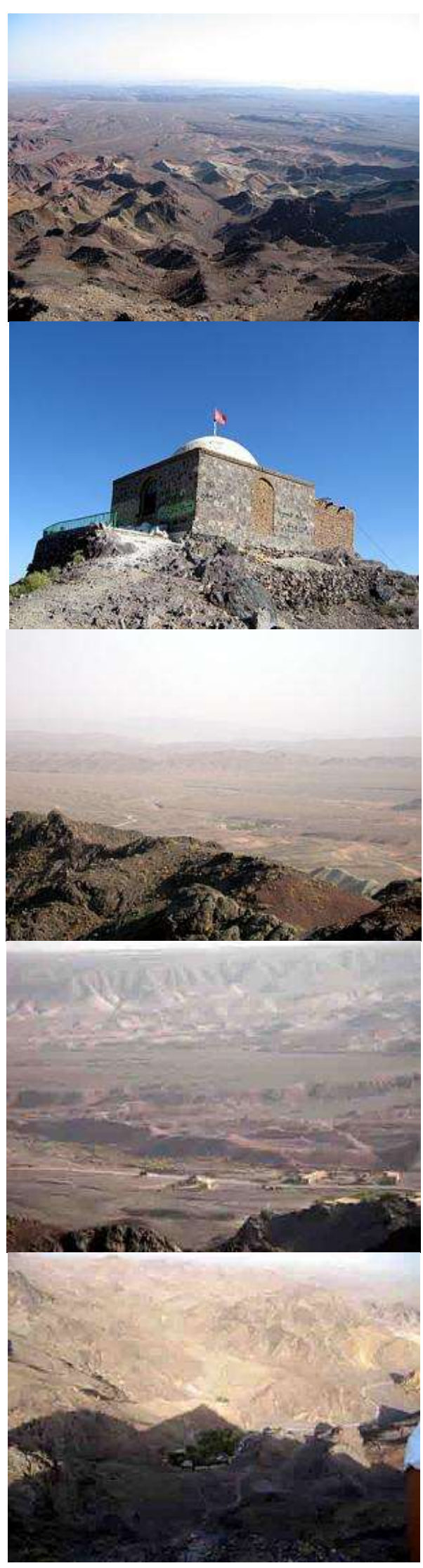

Fig 9. Historic monuments and geological aesthetics around it 
International Journal of Science and Engineering Applications

Volume 9 - Issue 06, 79 - 86, 2020, ISSN:- 2319 - 7560

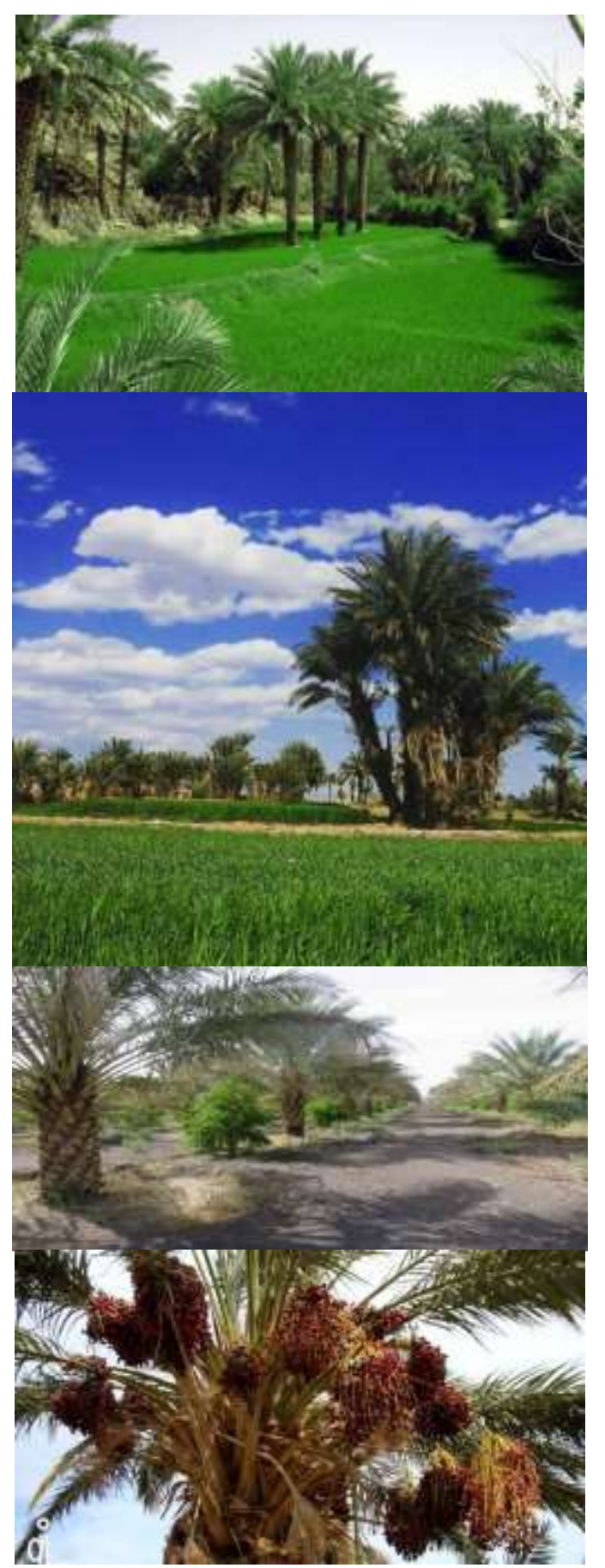

Fig 10. Palm trees in the Torud village
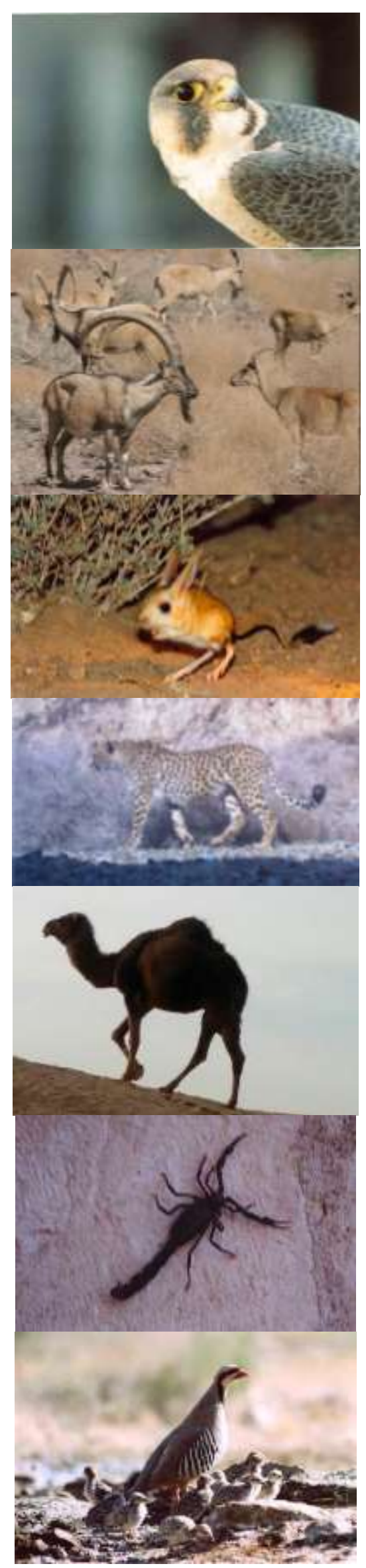

Fig 11. Some species of animals in the area 


\section{CONCLUSION}

The Toroud village is located in the southern part of the city of Shahrood, on the edge of the desert. Due to the specific situation of the village and the opinion of the village around it, the village has geologically diverse attractions for geologists and others. In addition to geological features that include desert, mines, geological phenomena and zeinous rocks, this area also has vegetation coverings and a variety of animal life. The geopark potential of this region can be seen in the area. These studies are important to the attention of the more authorities, and it is hoped that the results will also lead to other parts of our beloved country.

\section{REFERENCES}

[1] R. K. Dowling, "Global geotourism-an emerging form of sustainable tourism," Czech Journal of Tourism, vol. 2, no. 2, pp. 59-79, 2013.

[2] N. T. Farsani, C. O. Coelho, C. M. Costa, and A. Amrikazemi, "Geo-knowledge management and geoconservation via geoparks and geotourism," Geoheritage, vol. 6, no. 3, pp. 185-192, 2014.

[3] J. Larwood and C. Prosser, "Geotourism, conservation and society," Geologica balcanica, vol. 28, pp. 97-100, 1998.

[4] Z. Xun and Z. Ting, "The socio-economic benefits of establishing National Geoparks in China," Episodes, vol. 26, no. 4, pp. 302-309, 2003.

[5] R. K. Dowling and D. Newsome, Geotourism. routledge, 2006.

[6] S. Alahgholi, A. Shirazy, and A. Shirazi, "Geostatistical Studies and Anomalous Elements Detection, Bardaskan Area, Iran," Open Journal of Geology, vol. 8, no. 7, pp. 697-710, 2018.

[7] S. Khakmardan, A. Shirazi, A. Shirazy, and H. Hosseingholi, "Copper Oxide Ore Leaching Ability and Cementation Behavior, Mesgaran Deposit in IRAN," Open Journal of Geology, vol. 8, no. 09, p. $841,2018$.

[8] A. SHIRAZI and A. HEZARKHANI, "Predicting gold grade in Tarq 1: 100000 geochemical map using the behavior of gold, Arsenic and Antimony by K-means method," 2018.

[9] A. Shirazi, A. Shirazy, S. Saki, and A. Hezarkhani, "Introducing a software for innovative neuro-fuzzy clustering method named NFCMR," Global Journal of Computer Sciences: Theory and Research, vol. 8, no. 2, pp. 62-69, 2018.

[10] A. Shirazi, A. Shirazy, S. Saki, and A. Hezarkhani, "Geostatistics Studies and Geochemical Modeling Based on Core Data, Sheytoor Iron Deposit, Iran," Journal of Geological Resource and Engineering, vol. 6, pp. 124-133, 2018

[11] A. Shirazy, A. Shirazi, M. H. Ferdossi, and M. Ziaii, "Geochemical and Geostatistical Studies for Estimating Gold Grade in Tarq Prospect Area by KMeans Clustering Method," Open Journal of Geology, vol. 9, no. 6, pp. 306-326, 2019.

[12] A. Shirazi, A. Hezarkhani, A. Shirazy, and I. Shahrood, "Exploration Geochemistry DataApplication for $\mathrm{Cu}$ Anomaly Separation Based On Classical and Modern Statistical Methods in South Khorasan, Iran," International Journal of Science and Engineering Applications, vol. 7, pp. 39-44, 2018.

[13] A. G. Yalgouz-Agaj, L. Ardebil, and S. Karimdoust, "Identification of some of the geotourism sites in Iran," World Applied Sciences Journal, vol. 11, no. 11, pp. 1342-1347, 2010.

[14] UNESCO. "List of UNESCO Global Geoparks (UGGp)." http://www.unesco.org/new/en/naturalsciences/environment/earth-sciences/unesco-globalgeoparks/list-of-unesco-global-geoparks/

[15] A. Shirazi, A. Shirazy, and J. Karami, "Remote Sensing to Identify Copper Alterations and Promising Regions, Sarbishe, South Khorasan, Iran," International Journal of Geology and Earth Sciences, vol. 4, no. 2, pp. 36-52, 2018.

[16] A. Shirazi, A. Hezarkhani, A. Shirazy, and I. Shahrood, "Remote Sensing Studies for Mapping of Iron Oxide Regions, South of Kerman, IRAN," International Journal of Science and Engineering Applications, vol. 7, no. 4, pp. 45-51, 2018.

[17] K. Roustaei, "Archaeo-metallurgical reconnaissance of ancient mines and slag sites on the northern edge of the Dasht-e Kavir Desert, Iran," Iranica Antiqua, vol. 47, p. 351, 2012.

[18] N. Ambraseys and A. Moinfar, "The sessmicity of IRAN: The Torud earthquake of 12th february 1953," Annals of geophysics, vol. 30, no. 1-2, pp. 186-200, 1977.

[19] J. Stoecklin, "Structural history and tectonics of Iran: a review," AAPG bulletin, vol. 52, no. 7, pp. 1229-1258, 1968

[20] P. R. Christensen, "Formation of recent Martian gullies through melting of extensive water-rich snow deposits," Nature, vol. 422, no. 6927, pp. 4548, 2003.

[21] F. Mousazadeh and K. O. Salleh, "The influence of lithology and soil on the occurrence and expansion of gully erosion, Toroud Basin-Iran," ProcediaSocial and Behavioral Sciences, vol. 120, pp. 2014.

[22] C. S. Hurlbut and C. Klein, Manual of mineralogy (after James D. Dana). Wiley, 1977.

[23] A. crystals from Mexico, "Mohs scale hardness."

[24] J. D. Dana and W. E. Ford, Dana's manual of mineralogy for the student of elementary mineralogy, the mining engineer, the geologist, the prospector, the collector, etc. J. Wiley \& Sons, 1912.

[25] Y. Wang and E. Merino, "Self-organizational origin of agates: Banding, fiber twisting, composition, and dynamic crystallization model," Geochimica et Cosmochimica Acta, vol. 54, no. 6, pp. 1627-1638, 1990.

[26] R. Simmons and N. Ahsian, The book of stones: Who they are and what they teach. North Atlantic Books, 2015.

[27] J. W. Anthony, Handbook of mineralogy. Mineral Data Publishing, 1990.

[28] Shirazy, A., Shirazi, A., Ferdossi, M. H., \& Ziaii, M. (2019). Geochemical and Geostatistical Studies for Estimating Gold Grade in Tarq Prospect Area by KMeans Clustering Method. Open Journal of Geology, 9(6), 306-326. 